\title{
FACTORES Y CONDICIONES DE TRABAJO QUE INFLUYEN EN EL PROCESO DE IDENTIFICACIÓN PROFESIONAL DE LOS PROFESORES DE INFORMÁTICA EN POLONIA
}

\section{FACTORS AND WORK CONDITIONS SHAPING THE DEVELOPMENT OF PROFESSIONAL IDENTITY OF IT TEACHERS IN POLAND}

\author{
Beata Jakimiuk \\ The John Paul II Catholic University of Lublin
}

Fecha de recepción: 12 de junio de 2013

Fecha de aceptación: 29 de junio de 2014

Fecha de publicación: 30 de junio de 2014

\section{RESUMEN}

La identificación del perfil profesional de los profesores de informática es un asunto muy complejo. Implica el análisis de varias cuestiones y problemas relacionados con la preparación profesional, las condiciones de trabajo, las aptitudes individuales, las competencias y actitudes personales. El mecanismo de identificación profesional se refiere a la capacidad de asumir su papel de profesor e identificarse con sus compañeros de trabajo. Es decir, se trata de aceptar obligaciones, costumbres, comportamientos profesionales, valores y creencias propios de su círculo laboral. Además, se debe tener en cuenta que el tiempo para adaptarse a las condiciones de trabajo y las reacciones al cambio en el trabajo pueden variar. Los profesores de informática en Polonia llevan a cabo tareas distintas relacionadas, por una parte, con el trabajo didáctico, educativo y de cuidador $y$, por otra, con los temas a enseñar. Sobre todo, deben cuidar el funcionamiento óptimo de los equipos informáticos y velar por la seguridad del aula de informática. Su trabajo consiste también en estar al tanto de las nuevas tendencias, programas e instrumentos informáticos y en aconsejar a otros profesores que usan las tecnologías para la enseñanza. En lo que se refiere a la identificación profesional de los profesores de informática, no se trata sólo de adaptar al profesor a su círculo laboral. Se debe sobre todo explicarle aquellos comportamientos apropiados a su puesto de trabajo, estándares y valores aprobados en su escuela e involucrarle en la mejora de las condiciones de trabajo, el modo de trabajar y sus resultados. Los profesores de informática influyen a la sociedad en lo que se refiere al uso de nuevas tecnologías, motivo por el que es importante mostrar los factores que determinan su identidad profesional y, en consecuencia, los indicadores de calidad y eficacia de su trabajo. El artículo que presentamos a continuación trata de explicar distintos elementos que influyen en dicho perfil profesional como son la identificación profesional, el círculo laboral, sus tareas y obligaciones; para concluir con la presentación del análisis de las condiciones de la formación de identidad de los profesores de informática.

Palabras claves: Profesor de informática; Identidad del profesor; Identificación profesional; Tareas profesionales del profesor; Círculo laboral del profesor. 
Factores y condiciones de trabajo que influyen en el proceso de identificación profesional de los profesores de informática en Polonia

\begin{abstract}
Professional identification of IT teachers in Poland is a complex issue, concerning many aspects and problems connected with professional training, working conditions and individual capacities, competences and attitudes. Mechanism of professional identification concerns one's identification with role of a teacher and with the whole professional group. This means adaptation to duties, customs, professional behavior, values and beliefs preferred in a given professional environment. Also individual time of adaptation to working conditions and reactions for changes need to be considered here. IT teacher performs many tasks connected not only with their didactic and pedagogical tasks but also many specific tasks connected with the subject they teach. Above all he or she should take care for the proper equipment and security of a computer room where the classes take place. Moreover, an IT teacher also has to bring up to date their computer science knowledge, their familiarity with the new trends in IT, programs and tools. Among his tasks the counseling other teachers who use IT technologies in teaching. Professional identification of IT teacher is not only the adaptation to the work environment but also being part of the behaviour, norm and value system of the given school, which serves the improvement in work conditions, methods and effects. IT teachers have the strongest impact on society's adaptation to conscious use of new technologies. Therefore the recognition of factors determining their professional identification and consequently their work quality, is so important. The article familiarizes the notion of professional identification, work environment, professional tasks and duties of IT teachers and presents the analysis of the conditions of shaping the IT teacher's identity.
\end{abstract}

Key words: IT teacher; Teacher's identity; Professional identification; Teacher's professional tasks; Teacher's work environment.

\title{
1. INTRODUCTION
}

One of the currently realized directions of pedagogical action is the development of an information society, which should be prepared for the conscious and critical use of information technology media. The development of the Internet, as well as the ubiquitous use of new technologies, causes a massive number of varying transmissions to reach every person. Consequences of the mass use of new technologies include changes in the process of communication, related to the dominance of images over text and the spoken word. This causes the emergence of a new quality of behaviours and habits. At the same time there appears a marginalization of actions aimed at the development of critical thought, as well as actions directed at the students' moral sphere. This may create the conditions for the creation of a dehumanized social environment. In this situation a significant challenge before the education system is the preparation of society for the conscious use of new technologies (García, 2011), for which IT teachers are primarily responsible. Becoming a professional teacher is tied to the process of developing one's identification with one's occupation (Luehmann, 2007). It is the personal participation in performing various roles, functions and 
professional obligations, a constant search and finding oneself in the job of a teacher.

In the presented paper, the subject for analysis is the professional identity of IT teachers. The purpose of the research is to show the factors influencing the professional identity of IT teachers, and in consequence on their quality of work nad perceived professional satisfaction. The adopted method of research is the analysis of literature on topics related to the professional identity of IT teachers.

A variety of interesting elaborations have been written on the topic of the sense of identity and the teacher's identity (Knowles, 1992; Bullough, 1997; Volkmann \& Anderson, 1997; Connelly \& Clandinin, 1999; Abdelal, Herrera, Johnston \& McDermott, 2006; Akkerman \& Meijer, 2011), none of them however undertake the issue of the IT teacher's professional identity. This justifies the realisation of research of this topic, including an elucidation of the concept of personal identity, work environment, tasks and professional obligations of IT teachers, as well as the factors of identifying with the profession of IT teacher.

\section{TEACHER'S PROFESSIONAL IDENTITY}

Professional identity can be interpreted as a process accompanying a person's development or as an effect of said development in the form of finding oneself in a social and professional role. Identity is the association of a given person or social group with another person or social group in the cognitive and emotive aspects. It allows for the specification of that which is most significant for a given person or group, and enables the description of the person's or group's characterization. It is a process in which a person becomes similar to someone else, assumes their goals and behaviours.

The transition from becoming a teacher to performing the profession requires attaining at least a partial, basic professional identity. A fully shaped professional identity serves not only to identify oneself in the context of work, but also delivers a more general interpretation of actions and experiences, one's own or otherwise. In such an interpretation, professional identity is not just self-definition, but also a means for defining the world (Søreide, 2006) from the perspective and through performed work. It also means a specification of the range and quality of forming relations with other members of the education process. Through contact with others a teacher shapes his identity not only by learning what he should become, but also what he should not be. Professional identity thus understood is not a state, but a process 
Factores y condiciones de trabajo que influyen en el proceso de identificación profesional de los profesores de informática en Polonia

occurring in the context of interaction of people met in a work environment.

A teacher's professional identity is determined by the degree of associating oneself with one's profession and place of work, as well as work satisfaction. Full professional identity occurs when the teacher treats his work and profession as the basis of his life - however such a stance can in extreme cases turn to work holism. Correct identity is the association of oneself with the profession in a measure allowing for the appreciation of other values and participation in family and social life. Partial identity occurs when the teacher treats matters of work and school on equal terms with other areas of his or her personal life. It pertains to consciously selected behaviours and situations, which means that the teacher associates himself strongly with certain properties of his work, and not at all with certain others. The teacher realizes certain necessities or adjusts to the majority. The degree of the teacher's association with his profession influences his attitude and expresses itself in the emotional engagement in work, recognition of the rules and goals of common action, association of one's own interest with that of the school, responsibility for the proper functioning of the school. In full identity the teacher cares for the quality of his work and has a sense of professional dignity. Partial identity causes the teacher to be good performer of instructions, but show no activity or initiative. A lack of professional identity occurs when the teacher treats his job solely as a source of income. Such a situation causes the teacher to think exclusively about himself and avoid difficult situations. He or she is inclined to a job change under the condition of material gain.

Professional identity depends on factors both objective and subjective. These include: professional training, skills, abilities to fulfill duties, post held in school, organization of conditions for the attaining of good results and job satisfaction, payment system consistent with actual engagement, creation of development opportunities and achieving mastery. Professional identity favors job stability, which in the objective sense pertains to the situation of the superior recognizing the teacher as appropriate to work in his profession; in the subjective sense the teacher him- or herself recognizes that the performed work is suitable for his or her qualifications, abilities and aspirations. The correct situation is when the judgments of superior and teacher overlap. The degree of professional identity has a direct influence on the teacher's professional attitude, expressing itself in associating oneself with the post held and in responsibility for the proper functioning and development of the school he or she works in. 
The teacher's professional identity can be understood as a state of self-definition which is the sum of influences and interactions from the work environment. Professional identity can be influenced by the social status of the teacher's profession, which depends on whether or not the knowledge of the range of the teacher's tasks and professional duties is commonly known; whether or not the professional problems and the context of work are known. Therefore it is worth conducting an analysis of the work environment, as professional tasks and actions (Watson, 2006), and even the image of the teacher in society, which will enable an understanding of the process in which the IT teacher's professional identity is shaped.

\section{IT TEACHERS' WORK ENVIRONMENT}

When analyzing the work conditions of an IT teacher, one should mention all factors occurring in the workplace which have a significant impact on the teacher's quality of work. These include: school's location; building and room architecture; IT laboratory equipment; work atmosphere; relationship with students, teachers, parents and superiors (Richardson \& Placier, 2001); work time; tasks and duties; school work organization. One should also consider the specificity of the taught subject and its consequences.

IT education as an element of preparing young people to effectively function on the job market is present in all stages of education. Digital skills are also one of the key competence categories in European education systems (Eurydice Report, 2012). They include basic skills in the use of computers for the acquisition, judgment, storage, creation, presentation and exchange of information, as well as communication and cooperation via the Internet. The success of any plans regarding the creation of an information society, implementation of IT elements and IT education in schools depend primarily on the teachers.

IT teachers in Poland form a significantly large occupational group. In the 2010/2011 school year 46580 teachers were employed, whose main teaching specialty was computer science or information technology; also 4696 teachers of IT vocational subjects (Zarębska, 2012).

In recent years many projects were realized within European Funds, which have improved the state of computer equipment in primary schools, middle schools, high and post-secondary schools, practical and lifelong learning centers. Thus it can be assumed that IT education in Poland takes place in well-prepared, specialist laboratories. 
Factores y condiciones de trabajo que influyen en el proceso de identificación profesional de los profesores de informática en Polonia

This is particularly important, because the new basic education core curriculum includes a provision on the compulsory education of students in the scope of working with a computer and the application of information-communication technology starting with the first grade of primary school. After completing first grade, the student uses the computer on a basic level: starts a program using the mouse and keyboard, abides by the rules and limitations regarding the use of the computer, whereas the third grade student looks up and makes use of information, browses web pages, creates texts and images, is aware of the dangers of anonymous contact and sharing personal information. The next stage of education where students learn the basic rules of using the computer and information technology are grades four through six. The student uses the computer and its software to extend his knowledge; support the realization of topics from school subjects and fields of knowledge; utilize the Internet and e-mail; develop his or her own interests; adhere to ethical and legal rules. In subsequent stages of education the goals of IT teaching pertain to the safety of computer use, using computer networks and communicating. Students should search for, gather and process information from various sources, develop texts, images, numerical data, motifs, animations, multimedia presentations using a computer. They should solve problems and make decisions using a computer and an algorithmic approach. They should utilize computer technologies to extend their knowledge and skills in various fields and to develop their interests. They should also be aware of the social aspects of development and of the uses of computer science. In the third stage of education, on middle school level, students are prepared for an active and responsible life in information society within computer science class. They make a simple web page containing text, graphics or hyperlinks using a web page editor. In the next stage of education teaching computer science is realized on a basic and advanced level. The basic level includes acquiring skills of conscious, proficient and safe use of the computer and its software, as well as active use of new technology in everyday life. On the advanced level the student is prepared for the direction and scope of further computer science education. In the range of curriculum content the student designs databases, describes mechanisms related to data safety, selects algorithms to solve problems, applies basic classic algorithms. The last group of subjects consists of vocational classes conducted in technical schools and post-secondary schools teaching in the profession of computer science technician. Currently the education cycle in these establishments ends in an external exam confirming professional qualifications. In the teaching cycle issues are covered from the fields of operating systems and computer networks, programming, multimedia and computer graphics, as well as specialist classes. 
Analysis of goals and subjects of computer science education leads to the conclusion that in the occupation of the IT teacher there is a high degree of variability depending on the taught class, kind of school and stage of education. Independent of the differentiating criteria, all teachers are forced in the face of the challenges of modern times to constantly improve their competencies. Thus this professional group very numerously participates in various forms of self-improvement, conferences, courses, workshops, postgraduate studies - they learn continuously throughout their lives. This is a necessary condition to the development of the professional personality, which leads to professional educational action. There is no such thing as full competencies in the profession of teacher, as in the face of the changing world his or her qualifications usually need to be supplemented (Samuel \& Stephens, 2000). The teacher, despite apparent constancy and stability (Beauchamp \& Thomas, 2009), acts in unique educational situations, in which the possessed competencies may turn out to be insufficient. The teacher cannot succumb to routine, must be constantly open to new events and exceed that which he or she is and capable of. The work of a teacher means not only the transfer of knowledge, but primarily affecting the student with his or her personality, which requires constant development and is a part of his competencies. Because of this a teacher must be aware of how important in his professional and personal life is thought on his own work and on the shaping of professional identity (Cooper \& Olson, 1996). Teachers see with increasing clarity that their qualifications acquired at university are only the beginning of the road leading to the achievement of a high quality of teaching and educational action and development of professional identity.

One of the factors influencing the shaping of personal identity is the prestige of the teacher's profession. It is interesting that on one hand the profession of teacher for many years has constantly been held in high regard, and on the other is the object of numerous negative stereotypes. One of them is the myth of a teacher's short time of work. This belief causes the emergence of many critical judgments, which follow mostly from the time a teacher spends on directly working with students is shorter than the working hours of people in most other professions. In effect this causes prejudices and negative emotions regarding teachers.

According to many, teachers are failures who cannot find better paid work, and on the other hand we have opinions that teachers earn too much as is. It is also hard not to notice the general criticism regarding the effort that teachers must put into their work. The opinion is often repeated that teachers finish easier, teaching or pedagogical studies and are undereducated. Thus this professional group suffers 
Factores y condiciones de trabajo que influyen en el proceso de identificación profesional de los profesores de informática en Polonia

categorization with a wide range of negative traits which are automatically assigned to every teacher. Critical judgment of teachers makes a certain bond grow between them, a sense of solidarity, it also poses a certain challenge which leads to the mobilization of teachers in defense of their image (Borko, 2004). For this reason negative opinions on teachers are also one of the factors shaping the professional identity.

Stereotypes introduce a generalization of the major properties of the profession of teacher, because of which everyone who identifies him or herself with this professional group is labeled and may with time start to believe that he or she is also characterized by the stereotypical traits. This may result in the teacher not undertaking any bold action towards the betterment of work conditions for fear of criticism from students, parents, headmasters and the public opinion. It may also result in opportunism and apathy in all of the teacher environment, and in consequence lead to a lack of thought on one's own profession.

When analyzing the teacher's work condition, one should mention the stress that may accompany the teacher almost all of the time, as it is work in unusually difficult conditions. The teacher is in a situation of constant judgment from others and is often found in situations that challenge his or her abilities, competencies, or even views and behaviours. Sometimes he or she must react in a situation that requires a swift decision in events of conflict. Furthermore he or she is constantly laden with a large amount of information, necessity of activity and simultaneous performance of multiple tasks. All of these situations cause tension which in consequence may cause various disorders in the functioning of the organism and reduce efficiency of action. The work of a teacher depends not only on his or her knowledge and skills, but primarily intellect, emotions, ability to establish and maintain bonds with other people. There are no ideal tools of work for the teacher, because the most important tool he or she can count on is his or her own professional identity.

Shaping a sense of professional identity is tied to the development of competencies. Professional competencies have a direct influence on the quality and means of teachers' performance of given tasks. They are decisive in functioning in a group, building proper relationships with students, school employees (Alsup, 2006) or parents. Personality competencies are skills that ensure effective realization of goals in school situations during contact with other people. Thanks to them teachers are able to fully utilize their potential, specialist knowledge and professional experience. For it is worth keeping in mind that every teacher works with people and works for people, which at the same time is one of the factors of supporting the teacher (Burke \& Stets, 2009). It is the 
competencies of teachers that ultimately decide on the possibilities of effective performance of professional tasks (Ríos \& Gómez, 2013) and shaping of professional identity.

\section{PROFESSIONAL DUTIES OF IT TEACHERS}

A professional task is "a logical stage of work within the profession, a set of professional actions tied together with a common goal, ending with a specific product, service or decision" (Kwiatkowski, 2005, p. 8). The tasks of an IT teacher can be defined through the analysis of the core curriculum and IT class curricula in subsequent stages of education. The classification of professional tasks by school function leads to isolation of didactic, upbringing, pedagogical and specialist tasks (Beijaard, Verloop \&Vermunt, 2000).

Didactic tasks of the IT teacher are related to the planning, organization and realization of the teaching process - learning in a way that ensures the achievement of the goals of computer science education. They aim to enrich knowledge and develop the abilities to utilize computer equipment, apply its functions, use operating system services, work in a local and global network, solve problems using utility programs. These include: planning and conducting classes according to the realized goals; running IT interest groups; basic use of the computer: operating systems, applications and devices; installing and configuring computer programs and devices; using the English language, particularly IT vocabulary; use of computer programs to create and process text, create and process images, to perform calculations, to create and search databases; use of network operating systems and employing network and Internet services; protecting the computer from data loss and unwanted access; making use of application interaction and incorporating multimedia; writing one's own computer programs.

Upbringing tasks pertain to the intentional and conscious influence on the pupil undertaken with the goal of his or her comprehensive development and preparation for life in conformance with socially accepted values, with consideration for ethical issues related to the use of information technology. These include: conforming to legal regulations and moral norms in the use of new technologies; recognition of students' talents and interests; organizing teamwork through the realization of group projects; analyzing trends in computer science development; striving towards development and enrichment of IT knowledge; accustoming students with the use of knowledge and skills in typical situations and those requiring problem solving, as well as to cope in difficult professional situations; utilizing means and tools of information 
Factores y condiciones de trabajo que influyen en el proceso de identificación profesional de los profesores de informática en Polonia

technology in a critical and responsible manner; motivating students to work; building interpersonal relations through communication and teamwork; acquiring self-presentation skills and gaining self-confidence through presentation of the results of one's own work; shaping independence, responsibility and discipline in the performance of tasks, the will to constant professional improvement and striving towards development and enrichment of one's personality.

Pedagogical tasks pertain to the attention to safety and hygiene of working with a computer. These tasks include: ensuring a sense of safety during classes; eliminating mental and physical health hazards resulting from excessive or inappropriate use of equipment and software.

Throughout the entire period of his or her professional work the teacher also performs research tasks related to the diagnosis and analysis of the teaching-learning process. These include the analysis of the effects of schooling and attendance, as well as the search for didactic, methodical, organizational and technical solutions. Research tasks as an integral part of a teacher's work encompass, among others: identification of students' needs and abilities - recognizing, satisfying and developing; determining and the strong and weak sides of one's own work; evaluation of the realized curriculum content; gathering information regarding the effectiveness of the teaching and upbringing methods used in class; analysis of educational activity conducted by the teachers, pedagogue, psychologist and school management; compiling statistics on the effects of teaching in comparison to one's own and other schools; compiling statistics on test results and other grades received by students; analysis of students' learning progress and attendance; gaining didactic, methodical and organizational knowledge through individual search and through participation in training, courses, postgraduate studies. Furthermore, the IT teacher will find the following to be important: inventory of present hardware and software resources; learning current standards of hardware and software and directions of development of new technology. The IT teacher must face the necessity of constant further training in the field of new technologies, acquiring up-to-date knowledge and new skills.

In the work of the IT teacher each stage of education brings organizational tasks. The IT teacher must face the variety of computer hardware and software in school laboratories. Furthermore the teacher, when realizing the curriculum, has to organize work in his classes in such a way that students are unable to launch online messengers, computer games or other software which would divert their attention from the subject at hand. It is then his task to select the equipment, software and measures of security from unwanted access from outside or 
inappropriate use within the school. Among organizational tasks realized by the teacher one could list: providing optimal hardware and software for the realization of the curriculum and ability of students; establishing clear and understandable rules of using the laboratory; cooperation with people responsible for education - school management, parents, officials of the leading and supervising institution and other teachers; organizing action aimed at the popularization of the use and development of information technologies; making use of the ability to acquire funds for the modernization of hardware and software (Jakimiuk, 2012).

Professional tasks of the IT teacher are the basis for determining the structure of the professional qualification standard, which is formed by knowledge, skills and psycho-physical traits of the IT teacher. The qualification standard presents a level of basic requirements in terms of knowledge, skills and attitudes towards IT teachers' competencies.

Analyzing the components of the professional qualification standard indicates a diversity of performed didactic tasks and enables the identification of knowledge and skills of the IT teacher. Based on the research one can say that the post of IT teacher encompasses a much wider range of professional tasks than the range of duties related to the didactic, pedagogical and upbringing function of the school (Jakimiuk, 2012).

The IT teacher on each stage of education realizes didactic, pedagogical, upbringing, organizational and research tasks; however the number of these tasks depends not only on the stage of education, but also on the requirements set before the teacher by other members of the education process, namely students, parents, other teachers, employees of the supervising and leading institution, and primarily school management. He or she frequently performs many additional professional tasks, including holding the posts of IT advisor for other teachers or school website administrator.

In each stage of education the teacher should possess knowledge and skills from the field of computer science, including those related to new technologies or directions of their development, pedagogical and psychological knowledge, knowledge on occupational safety and health, organization of work and statistics, as well as procedures and methods of acquiring funds for hardware and software. Knowledge of the English language, which defines numerous IT terms, is indispensable in the higher stages of education - beginning with middle school. Subsequent stages of education require the teacher to possess an increasingly high amount of skills and increasingly broad knowledge; 
Factores y condiciones de trabajo que influyen en el proceso de identificación profesional de los profesores de informática en Polonia

where knowledge and skills of a middle school IT teacher are similar to those of a high school IT teacher. One should note that the knowledge and skills of an IT teacher will undergo modifications due to the fast development of computer and communication technology, resulting in changes in curriculum content of IT classes.

The profession of teacher comes with great social expectations. It is assigned tasks which are downright impossible to fulfill, which should be undertaken by many people and institutions, often even the methods and results of the teacher's work are subject to criticism. Due to this an important task is defining the standards of professional competencies of the teacher, who in modern times is faced with new requirements which follow from a dynamic situation, uncertainty of employment, preparedness to cope in an unknown future.

The teacher must also face the situation of increased professional mobility and that everyone will be forced to change or raise professional qualifications multiple times during his or her professional life. It is an effort of constantly taking up new challenges, finding oneself in a situation of sudden changes. Preparing one's pupils to coping in the changing world is one of the most important tasks in a teacher's work. To be able to meet these challenges, he or she must be appropriately prepared and have an appropriately shaped attitude and professional identity.

The teacher has an immense influence on the shaping of a student's personality and morality. Alongside behaviours taught and controlled by himself, the teacher always makes an influence, the source of which is his or her own personality. The development of a teacher's personality differs however from the development of those who are not professionally tied to education, as his or her becoming a person is not merely a personal matter, but becomes part of his or her professional preparation.

A teacher should inspire social and cultural action undertaken by students, which is why he or she should take interest in cultural events, easily navigate the world of modern events, have an unambiguous attitude, but allow the students to express their own opinions. If one of a pedagogue's actions towards his or her pupils is to be preparing them to participate in culture, then the pedagogues themselves need to be open to what happens in culture (Grave, 2005), know what new cultural competencies are essential, what traps lie in wait for the naïve pupil, but also for the incompetent teacher.

The teacher should also be able to discipline students, show them the value of work, while at the same time remaining a person whom they 
can trust and who is their advisor. Education eliminating effort, divorced from the labor of work, assuming a limitation of stress and tension does not prepare a young person to coping with the challenges of the changing world.

A teacher is a specialist in the scope of substantive knowledge of the subject he or she teaches. He or she must however be critical of his field, constantly questioning the legitimacy of basic problems and their solutions. A pedagogue is not just someone who has a specific knowledge, but also constantly increases it, who tries to achieve wisdom and act ethically to independently understand and explain the world, discover another person and help him or her in solving the most crucial of moral dilemmas. A teacher must apart from substantive knowledge possess certain traits necessary for performing the profession, which include: empathy, respect for other people, patience, ease of establishing and maintaining relations, communication competencies.

Effective realization of various tasks and duties is possible with identification with professional functions, conditions and context of work (Flores \& Day, 2006). Professional identity is formed with the active participation of the teacher him or herself, his or her readiness and thought on his or her work (Gee, 2001). Performing the profession of IT teacher requires not only substantive and methodical knowledge and numerous specialist skills, but also a fully formed professional identity, which belongs to the professional competencies of the teacher and has an essential role in the quality of work.

\section{FACTORS OF IDENTIFICATION WITH THE PROFESSION OF IT TEACHER}

A teacher's professional identity is shaped throughout his or her professional life, which is why it is worth considering how this process occurs and what an IT teacher's professional identity depends on. Formal competencies which grant the right to undertake professional work form the basis for the start of a professional career, but professional identity is not yet established at this stage. Often a beginning teacher faces a situation of a sense of incompetence, occasionally helplessness and terror. In this period he or she confronts the knowledge and skills gained at university with real professional work. Despite formally being an IT teacher he or she realizes that in in work he or she must still gain many new experiences and skills. Both beginning professional work and changing it, e. g. a change of school, stage of education or even the start of a new school year require answering many questions regarding the scope of professional activity. Primarily one needs to answer questions regarding possessed professional competencies. Thought 
Factores y condiciones de trabajo que influyen en el proceso de identificación profesional de los profesores de informática en Polonia

should pertain knowledge, skills and character traits or attitudes alike. Professional duties of an IT teacher mainly pertain to work with a computer, which requires specialist skills, but also theoretical preparedness in the field of computer science. It may turn out that knowledge and skills gained at university are insufficient and further training is required. In a teacher's work, relations with the people he or she meets at work are very important: teachers, superiors, students and their parents. A teacher should actively enter these relations, co-create them and take actions such that they are always at their best. He or she must cope with the variety of personalities and styles of behaviour while still maintaining one's own autonomy. In an IT teacher's work there occasionally are situations where he or she has to work alone, e. g. preparing a project, presentation etc. and situations when he or she works in a team of teachers. It is difficult to imagine that at the start of his or her professional path a teacher does not make mistakes and perfectly manages all events that come up at work. For that to be the case it takes time, experiencing various situations, taking on challenges, and primarily one's own activity, willingness to act and solve problems. From this it follows that the professional identity of an IT teacher is shaped during the performance of various professional tasks and duties, however it is difficult to say how long it takes for it to form. It depends on the amount and kind of performed professional tasks, but mostly on the teacher him or herself, on the teacher's thought on his or her work, and constant striving for growth. Through using the ability to interpret the world the teacher assigns meaning to everything that takes place in his or her surroundings, and the development of these competencies influences the pragmatic efficiency of the teacher's actions. A teacher works in a changing reality, and because of this effectively functioning in the profession requires constantly reinterpreting it. A teacher's work involves unique situations, in which one cannot always apply a course of action that worked well in another situation.

Development of an IT teacher's professional identity depends on whether or not the teacher identifies with the specificity of his or her profession and work conditions (Kelchtermans, 2009). Fields of undertaken activity are an important indicator of professional identity. An IT teacher is usually responsible for the laboratory in which his or her classes take place. His or her responsibilities include ensuring proper work conditions, hardware maintenance, updating software. In this way the teacher takes care for both his or her comfort and that of the students, which constitutes one of the factors of professional identity. In this field an expression of professional identity could be taking further steps towards improving learning conditions. 
Another aspect of professional identity can be the teacher's activity in other areas of the school reality. This pertains mostly to supporting and developing the knowledge and skills of one's students, e. g. hosting contests, tournaments, encouraging the use of new technologies, helping weaker and talented students, organising field trips, encouraging students to co-create the website, record important school events in the form of multimedia presentations, organising expositions of students' works etc. A significant role is played here teacher-student interactions, which likely constitute the most important source of a teacher's professional identity. In relation to a student a teacher learns what kind of teacher he or she is and if he or she is able to respond to the student's needs and expectations.

A significant factor of a teacher's professional identity is the total of experiences he or she gathers throughout work. These affect the content of one's impressions and decide on one's self-image. In this scope a significant role is played by time perspective. Representations of the past, present and future determine the mode of perceiving the world and functioning in one's profession (Tickle, 2000).

An IT teacher's strong professional identity is possible when the teacher is connected to his or her profession throughout all of his or her professional life, which is related to stable employment and determines a perspective of one's place in the profession. This is tied to the determining of the idea of performing the profession of IT teacher and defining the possibilities of one's development and the development of one's students.

A teacher acts within the boundaries of a defined system of norms and procedures, sometimes is subject to pressures and duress, however a formed professional identity helps him or her retain complete freedom and solve problems in a way that is optimal in the present conditions, without limiting the perspectives of one's development.

An important factor that shapes professional identity is the occurrence of crisis situations which force the teacher to react, make choices which lead to the undertaking of certain actions. In this way the teacher acquires new experiences which may strengthen professional identity, however in a situation where obstacles turn out to be too difficult to overcome there may occur discouragement, and as a result noticing and looking for shortcomings of the performed work and a loosening of one's ties with the profession.

The shaping of a teacher's professional identity is a complex process in which various situations may occur. Professional identity 
Factores y condiciones de trabajo que influyen en el proceso de identificación profesional de los profesores de informática en Polonia

involves an extended period of searching, experimenting, testing one's strengths and trying different options. Professional identity is the effect of an in-depth examination of oneself by the teacher, of his or her abilities and conditions for action. It also involves an awareness of one's values, needs, views and attitudes (Cohen, 2010), which form the ethical basis for one's work. This kind of identity is characteristic to the teacher who has solved the crisis situation, is engaged in specific actions and knows the answer to the questions: Who am I? Who do I want to be? (Beijaard, Meijer \&Verloop, 2004) In this situation one can say that the teacher has a fully formed professional identity.

An IT teacher with this kind of professional identity is autonomous in his agency and relatively independent from external influences. Problems appearing at work he or she treats as a challenge, which lets the teacher put his or her competencies to a test and find his or her own means of solving it. Such teachers possess personal maturity, are prepared to plan and realize their professional growth. They are aware of who they are and who they want to be. A clearly defined identity helps them in forming good relations with students and other people. They do not feel threatened, because they know that they can cope in situations of conflict. An expression of an IT teacher's full professional identity is constant thought on one's own work, which leads to undertaking action related to the growth of one's own competencies, and also enables coping with varying school situations and the dynamic development of new technologies.

\section{CONCLUSIONS AND DISCUSSION}

Professional identity is a process which takes time, adaptation to one's work conditions (Akkerman \& Meijer, 2011), undertaking characteristic professional tasks and actions. Shaping identity is related to engagement in one's work, own effort, coping with professional difficulties. The professional identity process occurs in a work environment typical for the profession at hand, because of this considerations on the subject should pertain to a given professional group and a specific profession within that group. Content presented in this paper may constitute a basis for the analysis of professional identity of the teacher environment in its entirety, as well as the profession of a teacher of a specific subject with consideration for the specificity of his or her work.

In teaching professions there is a very high degree of differentiation based on the taught subject, kind of school, stage of education. Regardless of the differentiating factors, all teachers are in the face of the challenges of modern times forced to constantly raising 
their competencies. Thus this professional group numerously participates in various forms of improvement, conferences, courses, workshops, postgraduate studies, and therefore learns throughout the entirety of their lives. This is a vital condition of the development of professional identity, which leads to professional educational action.

In the profession of teacher there is no such thing as complete professional competencies, as in the face of the changing world qualifications generally require supplementation. A teacher, despite appearances of constancy and stability, works in unique educational situations, in which the possessed competencies may prove insufficient. A teacher cannot succumb to routine, must be constantly open to new events and going beyond what he or she is and can. The work of a teacher means not only imparting knowledge, but primarily affecting the student through his or her personality, which requires constant development and is part of the teacher's competencies. Because of this a teacher has to be aware of how important participation in education throughout his or her life is to his or her professional life (Day, 1999). The changing school environment and surroundings make teacher see increasingly clearly that their qualifications acquired at university constitute only the beginning of the path leading to the betterment of didactic-pedagogical action and the development of professional personality.

Formal qualifications determined by ranks on diplomas and certificates are not the same as real competencies, evident through specific action. Thus lifelong training of teachers is particularly important, especially in the case of those which have reached a phase of stagnation in their profession.

The development of professional identity is an essential condition of good organization and realization of didactic and upbringing actions. An effect of fully formed professional identity is the occurrence of observable changes of a teacher's competence level in the form of particular educational achievements. This means positive and desirable for students' development changes in the quality of the teacher's behaviour, as well as the development of his or her personality. It is worth keeping in mind that the development of a teacher's professional identity takes place through his or her active participation in the process of work and education throughout his or her entire life.

Analysis of the conditions of teacher's professional identity development leads to the isolation of two groups of factors: 
Factores y condiciones de trabajo que influyen en el proceso de identificación profesional de los profesores de informática en Polonia

- external, related to the work conditions of teachers, the education system, workplace, curriculum, organization of teacher training;

- internal, related to personal efforts, striving to the development of one's knowledge and skills, attitude towards changes, way of using one's own predispositions and abilities in relation to current conditions and circumstances.

A condition for the development of professional identity is dominance of internal factors over external ones. Only then can a teacher control a situation, manage and organize work conditions, make choices and realize related activity. This is tied to the taking of personal responsibility for one's decisions and behaviour.

Professional identity on one side is related to work satisfaction, on the other side however it means a certain tendency towards dissatisfaction which leads to constant thought on one's competencies and work conditions, and a drive to improve the situation. The search does not exclude improvisation and making mistakes from which the teacher should draw conclusions. In this scope a teacher can also consider the opinions and tips of others and subject them to critical analysis. This pertains also to the ability to notice changes in the surrounding world, adjusting to them, as well as controlling and using them to improve oneself and others.

A teacher identifying with his or her profession always shows an individual approach to every student using the properties of the group he or she is a part of. Because of this one of the significant indicators of professional identity that can be observed is the way of forming and maintaining relations with one's pupils.

In the work of a teacher it is not only important to impart knowledge and shape skills, but primarily to teach integrally, holistically, forming a proper attitude, specifically a need to learn.

Shaping professional identity takes an immense effort on the part of the teacher, as it is related to taking responsibility for the development of both the teacher and the students. Because of this a decisive factor is the teacher's activity (Beijaard, Meijer \&Verloop, 2004; Luehmann, 2007) in this scope reflected through the constant drive to the professional performing of one's duties.

The professional identity of computer science teachers means identifying with the profession of teacher, as well as with the professional group of teachers of this particular subject. Through identification with 
the held professional role the teacher defines his or her place in society. Professional identity of a teacher is built on relations with others and shaped during work at school. An IT teacher's professional identity combines theory with practice. It is a subjective factor determining the teacher's quality of work. It provides a basis for the critical analysis of previous forms and methods of teaching. The development of an IT teacher's professional identity requires an open approach and readiness for change. One of the conditions of development is being a reflective practitioner, which means constant training in the field of the taught subject's theory, searching for better methods of teaching, acquiring new skills and a constant cognitive curiosity not only in the scope of knowledge and practical activity, but also taking an interest in another person. Despite the growth of competencies depending on the modification of already possessed knowledge, skills and attitudes and it expressing itself in behaviour in practical situations, one cannot relate it solely to the technical aspects of agency. Computer science education, which relies to a large degree on practical skills and takes place mostly in computer laboratories, would not be possible without a theoretical introduction. IT teaching in the face of the fast pace of new technology requires that the teacher constantly learns and acquires new skills. This is a basic characteristic of the profession of IT teacher and his or her professional identity requires acceptance of the particular conditions of the work environment, specific professional tasks and duties. However this acceptance and association with the professional role held are only possible after deep thought on one's own work.

Conclusions regarding the factors that determine the shaping of IT teachers' professional identity pertain to both theoretical and practical issues. First of all, one should conduct research on the profession of teacher, his or her professional tasks and actions, work conditions, characteristic problems that occur at work and the methods of solving them, threat and crisis prevention and determining optimal means of supporting the growth and professional functioning of teacher, developing programs, methods and techniques of training and professional improvement of teachers.

Development of professional identity plays a key role in the teacher's professionalism, which is why it requires external support. Supporting the development of teachers' professional identities should take place within the bounds of the system which will be at least partly financed from the national budget, there should also be people appointed to be responsible for the undertaking of such actions. Currently in Poland many courses for teachers require fees. Considering the fact that teachers in Poland do not earn a lot, their access to these is limited. Furthermore it is important for courses to involve dedicated 
Factores y condiciones de trabajo que influyen en el proceso de identificación profesional de los profesores de informática en Polonia

groups, where the content of courses should reflect actual needs of teachers. Courses suggested to teachers are frequently subject to criticism, as they do not meet expectations and are usually led by people unfamiliar with the realities of schools and the problems of teachers. It appears that the scope of actions undertaken in relation to the support of teachers is insufficient, and the problems related to these issues are absent in the public space. Teachers shape the development of children and youth, which is why it is worth supporting the forming of their professional identity. Because of this it is important to undertake deeper, multidisciplinary and systematic research regarding the subject matter at hand, which will enable the design of effective practical activity pertaining to the education and developmental support of teachers.

\section{REFERENCES}

Abdelal, R., Herrera, Y., Johnston, I., \& McDermott, R. (2006). Identity as a variable. Perspectives on Politics, 4, 695-711.

D.O.I.: http://dx.doi.org/10.1017/S1537592706060440

Akkerman, S. F., \& Meijer, P. C. (2011). A dialogical approach to conceptualizing teacher identity. Teaching and Teacher Education, 27, 308-319.

D.O.I.: http://dx.doi.org/10.1016/i.tate.2010.08.013

Alsup, J. (2006). Teacher identity discourses: Negotiating personal and professional spaces. Mahwah, N.J.: Lawrence Erlbaum Associates.

Beauchamp, C., \& Thomas, L. (2009). Understanding teacher identity: an overview of issues in the literature and implications for teacher education. Cambridge Journal of Education, 39, 175-189. D.O.I.: http://dx.doi.org/10.1080/03057640902902252

Beijaard D., Verloop N. \& Vermunt J. D. (2000), Teachers' perceptions of professional identity: an exploratory study from a personal knowledge perspective. Teaching and Teacher Education, 16, 749-764. D.O.I.: http://dx.doi.org/10.1016/S0742-051x(00)00023-8

Beijaard, D., Meijer, P. C., Verloop, N. (2004). Reconsidering research on teachers' professional identity. Teaching and Teacher Education, 20, 107-128. D.O.I.: http://dx.doi.org/10.1016/i.tate.2003.07.001

Borko, H. (2004) Professional development and teaching learning: Mapping the terrain. Educational Researcher, 33(8), 3-15. http://dx.doi.org/10.3102/0013189X033008003

Bullough, R. V. (1997). Practicing theory and theorizing practice. In J. Loughran, \& T. Russell (Eds.), Purpose, passion and pedagogy in teacher education (pp. 13-31). London: Falmer Press.

Burke, P. J., \& Stets, J. E. (2009). Identity theory. New York: Oxford University Press. 
D.O.I.:nttp://dx.doi.org/10.1093/acprof:0so/9780195388275.001.000 1

Cohen, J. L. (2010). Getting recognised: Teachers negotiating professional identities as learners through talk. Teaching and Teacher Education, 26, 473-481.

D.O.I.: http://dx.doi.org/10.1016/j.tate.2009.06.005

Connelly, F. M., \& Clandinin, D. J. (1999). Shaping a professional identity: Stories of education practice. London: Althouse Press.

Cooper, K., \& Olson, M. R. (1996). The multiple 'I's' of teacher identity. In M. Kompf, W. R. Bond, D. Dworet, \& R. T. Boak (Eds.), Changing research and practice: Teachers' professionalism, identities and knowledge (pp. 78-89). London/Washington, DC: The Falmer Press.

Day, C. (1999). Developing teachers, the challenge of lifelong learning. London, Philadelphia: Falmer Press.

European Commission/EACEA/Eurydice (2012). Developing Key Competences at School in Europe: Challenges and Opportunities for Policy - 2011/12. Eurydice Report. Luxembourg: Publications Office of the European Union.

Flores, M. A., \& Day, C. (2006). Contexts which shape and reshape new teachers' identities: A multi-perspective study. Teaching and Teacher Education, 22, 219-232.

D.O.I.:http://dx.doi.org/10.1016/i.tate.2005.09.002

García C. M. (2011). La escuela, espacio de innovación con tecnologías. Revista Fuentes, 11, 86-105.

Gee, J. P. (2001). Identity as an analytic lens for research in education. In W. G. Secada (Ed.), Review of research in education, Vol. 25 (pp. 99-125). Washington, DC: American Educational Research Association.

Grave, E. (2005). Theorizing and describing preservice teachers' images of families and schooling. Teachers College Record, 107(1), 157185. D.O.I.: http://dx.doi.org/10.1111/j.1467-9620.2005.00461.x

Jakimiuk B. (2012). Standard kwalifikacji zawodowych nauczycieli przedmiotów informatycznych. Lublin: Wydawnictwo KUL.

Kelchtermans, G. (2009). Who I am in how I teach is the message: selfunderstanding, vulnerability and reflection. Teachers and Teaching, 15, 257-272.

D.O.I.: http://dx.doi.org/10.1080/13540600902875332

Knowles, G. J. (1992). Models for understanding pre-service and beginning teachers' biographies: Illustrations from case studies. In I. F. Goodson (Ed.), Studying teachers' lives (pp. 99-152). London: Routledge.

D.O.I.:http://dx.doi.org/10.4324/9780203415177_chapter_4

Kwiatkowski S. M. (2005). Problemy terminologiczne $w$ procedurach standaryzacji kwalifikacji zawodowych. In S. M. Kwiatkowski (Ed.) 
Factores y condiciones de trabajo que influyen en el proceso de identificación profesional de los profesores de informática en Polonia

Kwalifikacje zawodowe na współczesnym rynku pracy (pp. 7-15). Warszawa: Instytut Badań Edukacyjnych.

Luehmann, A. L. (2007). Identity Development as a Lens to Science Teacher Preparation. Science Education, 91 (5), 822-839. D.O.I.: http://dx.doi.org/10.1002/sce.20209

Richardson, V., \& Placier, P. (2001). Teacher change. In V. Richardson (Ed.), Handbook of research on teaching (pp. 905-947). Washington, DC: American Educational Research Association.

Ríos, J. M. \& Gómez, E. R. (2013). Relación entre competencias básicas de los estudiantes y competencias del profesorado. Revista Fuentes, 14, 209-230.

Samuel, M., \& Stephens, D. (2000). Critical dialogues with self: Developing teacher identities and roles-a case study of South Africa. International Journal of Educational Research, 33(5), 475-491. D.O.I.: http://dx.doi.org/10.1016/S0883-0355/00)00030-6

Søreide, G. E. (2006). Narrative construction of teacher identity: positioning and negotiation. Teachers and Teaching: Theory and Practice, 12(5), 527-547.

D.O.I.: http://dx.doi.org/10.1080/13540600600832247

Tickle, L. (2000). Teacher induction: The way ahead. Buckingham, Philadelphia: Open University Press.

Volkmann, M. J. and Anderson, M.A. (1997). Creating professional identity: Dilemmas and Metaphors of a first-year chemistry teacher, Science Education, 82(3), 293-310.

D.O.I.:http://dx.doi.org/10.1002/(SICl) 1098-

237X(199806)82:3<293::AID-SCE1>3.0.CO;2-7

Watson, C. (2006). Narratives of practice and the construction of identity in teaching. Teachers and Teaching: Theory and Practice, 12(5), 509-526. D.O.l.: http://dx.doi.org/10.1080/13540600600832213

Zarębska J. (2012). Nauczyciele w roku szkolnym 2010/2011. Warszawa: Ośrodek Rozwoju Edukacji. 


\section{Sobre la autora:}

\section{Beata Jakimiuk}

bjakimiuk@kul.pl

PhD in Pedagogy, Assistant Professor in Psychopedagogy Department of Pedagogy Institute at John Paul II Catholic University of Lublin. She has done research concerning standard professional qualifications, these include defining its standard elements: knowledge, skills and psychophysical characteristics, referring to professional tasks of an IT teacher. She is author of numerous articles about supporting professional development and career and a book Standard kwalifikacji zawodowych nauczycieli przedmiotów informatycznych (Standard professional qualifications of IT teachers). She has also been responsible for scholarly and critical editing of book Między wychowaniem a kariera zawodowa (Between education and career). Currently she carries out research concerning lifelong career, its characteristics, conditions, determinants and research of conditions of professional success development of personal and professional competences, preparation for professional life and functioning in the job market in the context of lifelong education as well as research about sources of professional satisfaction of teachers.

\section{Para citar este artículo:}

Jakimiuk, B. (2014). Factores y condiciones de trabajo que influyen en el proceso de identificación profesional de los profesores de informática en Polonia. Revista Fuentes, 15, Junio, pp. 213-236. [Fecha de consulta: dd/mm/aaaa]. http://www.revistafuentes.es/ D.O.I.: http://dx.doi.org/10.12795/revistafuentes.2014.i15.10 
Factores y condiciones de trabajo que influyen en el proceso de identificación profesional de los profesores de informática en Polonia 